\title{
perifèria
}

Number 18, june 2013

http://revistes.uab.cat/periferia

\section{Beyond 'adoption': the social relevance of informal child circulation $^{1}$}

Jorge Grau Rebollo. Universitat Autònoma de Barcelona. ${ }^{2}$

\begin{abstract}
Despite its prevalence in academic research, formal adoption is actually a specific sort of child placement. The more general phenomenon of the circulation of children could better help us to explain the centrality of minors in broader social milieus, since so-called 'informal' placements do frequently act as productive and reproductive strategies with social cohesion purposes that go far beyond the specificity of the punctual child transfer. These forms of child mobility are commonly found in many cultures, including our own in a not so distant past and may become a crucial social structuring factor.
\end{abstract}

Keywords: Circulation of children, Adoption, Kinship, Informal placements, Crosscultural Research.

\section{Resumen}

Pese a su prevalencia en la investigación antropológica, la adopción formal no es sino una forma más de emplazamiento infantil. Considerar, desde este punto de vista, la circulación de menores como un fenómeno más amplio de movilidad y adscripción podría sernos de más ayuda a la hora de explicar la centralidad de niños y niñas en contextos sociales diversos, puesto que los emplazamientos considerados 'informales' actúan con frecuencia como estrategias productivas y reproductivas con finalidades socialmente cohesivas que van más allá de la transferencia puntual de un menor. Estas formas de movilidad infantil han sido (y en buena medida siguen siendo) comunes en muchas culturas, también en la nuestra, pudiendo llegar a constituir un factor social estructurante.

Palabras clave: Circulación de niños/as, Adopción, Parentesco, Emplazamientos informales, Investigación Transcultural.

\footnotetext{
1 This article presents some results of my participation in the Research Project SEJ2006-10864, Teoría transcultural de la reproducción de los grupos humanos. La antropología del parentesco como estudio de los modelos socioculturales de procreación y crianza de los niños [Cross-Cultural Theory of the Reproduction of Human Groups. The Anthropology of Kinship as the Study of Sociocultural Models of Procreation and Upbringing], leaded by Dr. Aurora González Echevarría and funded by the Spanish Ministry of Education and Science.
}

2 Enviar correspondencia a: jordi.grau@uab.es. 


\section{perifèria}

Number 18, june 2013

http://revistes.uab.cat/periferia

\section{Introduction}

Adoption, among other kinds of foster care and under its different forms and typologies, has focused much of the academic, political, social and media attention in recent decades. Particularly, the growing impulse of international adoption within some Western countries has underlined the multiple corollaries that lay beneath the adoption process and that ultimately do shape it (as, for example, the notion and implications of 'abandonment' or some debates about different and multiple forms of parenthood and parental care). Among many other things, adoption makes visible folk ideologies in relation to the basic fields of identity, substance, legitimacy or inclusion, which occasionally intersect with debates over immigration, belonging and naturalization (Howell 2006). Such ideological notions also bring cultural assumptions about the final responsibility over children to the forefront, which aim at deeper social convictions on visible forms of group reposition and adscription of its members to the group's minimal constituent units. Moreover, adoption sets up a process of kinning (Howell 2006) that complete the transformation of a child into a social being by inserting him/her into a particular family where s/he becomes the crucial link between the past $s /$ he is inscribed into and the future $s /$ he is called to implement.

This multiple adscription of the adoptive child (as a member of a new family, of a new kin group, of a new circle of social relationships and of a new local community) should be necessarily combined with the outcomes of certain general and particular variables that influence (if not determine) the adscription procedure. Although several academic disciplines have successfully approached many of these variables by carefully addressing different parameters that may help to clarify developmental traits, adaptation conditions or catching-up processes, some issues do still recurrently appear as context-related items of considerable theoretical incidence e.g. the very concept of 'adoption' or 'being adopted'. In order to properly enlighten them, one should first try to understand the circumstances that surround the socalled adoption within origin and placements contexts -i.e. analyzing the diversity of placement forms, their complexity, as well as their local signification and social 


\section{perifèria}

Number 18, june 2013

http://revistes.uab.cat/periferia

reach.

Parallel to particular fieldwork researches worldwide, the ethnographic enquiry based on academic literature and archive sources may be of paramount help in this task. A thorough knowledge of the social and cultural conditions within which this phenomenon takes place in every particular culture and society, may also help to reveal the wide social connective networks that often surround (and are affected by) the placement of children.

My aim in this paper is to show how the culturally diverse ways of circulating children do not merely entail a change in the child's adscription, but how they also overtly act as productive and reproductive strategies with social cohesion purposes. Many times, such circulation has been labelled as informal (Tschopik 1951; Borges 1994 and Beatty 2002, among others), though this apparent lack of formal constitution should by no means be confused either with a careless planning of the child transfer nor with a diminished interest on the child him/herself. As Cecilie Øien points out: "[...] informal child circulation and kinship care are social practices that can create, maintain or lessen the amount of social capital of the people implicated -depending on the particular context they find themselves and are judged within." (2006:1105-1106).

For this purpose it is essential to take into consideration the various social practices of informal placement of children as reproductive -and also sometimes productivestrategies as well as social cohesion tactics that go far beyond the specificity of the punctual child transfer. Such an analytical approach allows us to limit the pernicious effects that the projection of ideological and theoretical ethnocentric statements may have upon the consideration of research phenomena. Also, it contributes to overcome analytical limitations in certain approaches to the contextual nature of formal placements and their corresponding cultural elaborations by providing a broad comparative spectrum and also by considering some anthropological, sociological, demographic and historical studies focused on Western societies.

If we assume that child placements do culturally entail a whole range of social 


\section{perifèria}

Number 18, june 2013

http://revistes.uab.cat/periferia

attitudes and understandings that go beyond any specific movement, then a broad array of theoretical possibilities would open up by considering: (a) social reproductive strategies where children play a significant role, and (b) the interconnection of these strategies with several contexts, since child placement does not merely involve, as I mentioned previously, a shift of adscription. Rather, it merges with cultural practices that bind people together (some of whom may have been previously connected by different social links). Once culturally specific notions are taken into account we can plainly understand, for instance, why some legal assumptions regarding adoption do openly collide with local practices of temporary placement (Panter-Brick 2000), or why social institutions like servanthood have been largely ignored within this conceptual framework.

Although major topics in current research tackle with a specific form of formal adscription -legal adoption-, my intention here is to show how ethnography makes visible different forms of child informal placement and how other social sciences have dealt with specifically European related practices -sometimes overlooked since nonbiological relations of this kind are no part of some conceptions of kinship-, thus facilitating the cross-cultural comparison and illuminating a better understanding of this issue.

Actually, we may find that some sources do often classify some of these placements as 'informal' and consequently do consider them differently from 'proper' (formalized) adoptions, while other references generically label both types (formal and informal transfers) as 'adoptions'. Nevertheless, we should notice that 'informal' children mobility could be traced in every continent on Earth, within different historical periods and under various forms. The extraordinary dimension of this circulation and the relevance it shows in several societies do suggest a combination of agents' interests in these agreements: the child him/herself, the adults involved in the transfer and the group as a whole. That is why the circulation of children could be regarded as a potential structuring social factor.

Indeed, the identification of children transfers with mobility and formal placement would largely restrict the field of action. It would do so from a methodological point

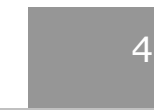




\section{perifèria}

Number 18, june 2013

http://revistes.uab.cat/periferia

of view, by leaving aside all non-formal placement variations that may have similar -or even broader- effects among social groups. Also, it would become restrictive in a practical sense. First, there exist societies with a minimal use of formal placements, but with effective formulae that do entail a binding agreement between the concerned parties. And second because, even among Western societies, child mobility under ways different from adoption have been in a not so distant past relatively frequent practices, sometimes covering broad social sections.

\section{The cross-cultural relevance of the circulation of children}

A close look at the ethnographic repertoire proves children transfers to be of uttermost importance for settling agreements among adult members of human groups, well beyond the strict procreative dimension. In this light, by transcending the mere mobility between households and places, the analysis of the circulation of children could clearly shape this transfer as a social strategy with cohesive purposes from a social point of view that highlights the centrality of childcare, whereas this care is connected to broader cultural traits regarding social control or economic organization, for example.

To refer this broad phenomenon as 'circulation of children' may cause discomfort in some social contexts, maybe due to its mercantile connotations or to its assimilation to illegal practices of trafficking or people slavery. In our discipline, the notion of 'circulation' is well known since the classical essays from Marcel Mauss (1924), who consider the gift and its circulation as a social cornerstone for human relationality, or Lévi-Strauss (1949), who did also refer to the female mobility among men-ruled human groups for alliance purposes in terms of circulation. Specifically concerning children, Lallemand (1993) mentioned their "circulation" in her study of child placements in traditional societies, and even more recently, Jessaca B. Leinaweaver (2008) or Marre and Briggs (2009) have also employed it.

In that sense, there have been some attempts to define it as a theoretical concept (Grau Rebollo 2010). Uche Isiugo-Abanihe considered it: "the transfer, giving out or exchange of children among families" (Isiugo-Abanhie 1985:53) and Fonseca refers 


\section{perifèria}

Number 18, june 2013

http://revistes.uab.cat/periferia

to this phenomenon as: "the transfer of nurturance responsibility for a child from one adult to another' (Fonseca 1986:15; quoted in Øien 2006). In this light, Leinaweaver has defined circulation as: "the relocation of a child or young person into a new household for locally meaningful reasons. These may include accompanying a lonely adult or obtaining better life opportunities for the child". (2007:164).

After gathering information and processing ethnographic data looking specifically for references to the adoptive practices and other ways of child placement worldwide, I propose to define circulation of children as the temporal or enduring transfer, which is potentially reversible, of children between adult people who may be previously bound by familial ties and who may share responsibilities over the child's care as well as the authority over the child's behaviour. Such transfer, often handled in 'informal' ways, does usually entail for the child the change of his/her residence and it may have major effects upon his/her adscription, inheritance and succession at the bosom of receiving groups and families. However, it neither demands the discontinuation of the child's relationship with his/her biological parents nor a complete disconnection between the nucleus of origin and placement (Grau Rebollo 2011a:41).

Actually, not only children are the basic social capital a group holds for the future (Fox 1967), but they also become a fundamental ingredient for adult current and forthcoming relational strategies. Hence, Claude Meillassoux highlighted the relevance of mobility as the basic resource for social reproduction (1975), though he explicitly referred to adult individuals. Such mobility would follow a cultural logic rather than biological needs, since human beings do not only have offspring, but they also perpetuate membership within social groups according to specific cultural rules. Hence, the control of procreation becomes a crucial task. It is this cultural premise of social mobility that could also be applied beyond adult members of a particular society.

Actually, ethnographic data may allow us to consider also the mobility of children in a similar light. Suzane Lallemand (1993) already suggested some connections 


\section{perifèria}

Number 18, june 2013

http://revistes.uab.cat/periferia

between child circulation and alliance (cfr. Parkes 2003: 744) and this articulation may resize children as collective assets well beyond their mere consideration as links for perpetuating descent lines or filiation groups. Thus, their circulation would appear as an essential part of adult strategies for mutual relationship, group cohesion and social improvement (Grau Rebollo 2010: 219).

In this direction, Leinaweaver assures that child circulation: "[...] produces relatedness and reproduces social connections and inequalities" (2008:164), and builds kinship relations as well: "The accustoming triggered by the transfer of a child can produce kinship, so it makes sense that child circulations are broadly viewed as a strategy for the amplification and consolidation of family" (Id.: 172). Moreover, in Ayacucho, where the research was carried out:

Child circulation is a vital method of producing relatedness, reproducing social connections, and reiterating relations of inequality [...] At the same time, it is a way in which people strive to get ahead and support their kin in a context of poverty and violence (Id.: 173).

But, could this strategy be traced back in early ethnographic accounts? As I have addressed elsewhere (Grau Rebollo 2010: 217-219), Parkes (2003) refers to fictive kinship or fosterage as a prominent locus by the late XIX Century. Maine (1861) had seen in it a social strategy oriented at finding an heir for a man's property. But we can find more revealing examples across ethnography. Robert Lowie briefly referred to adoption as early as 1930, Raymond Firth (1963 [1936]) mentioned the practice of the "adhering child" during his fieldwork among the tikopia, Evans-Pritchard (1940) also dealt with adoption among the nuer, Fortes (1949) highlighted the role of adoption as potential way of acquiring group membership for non-agnate individuals among the tallensi, Burridge (1958) published an article on adoption in Tangu and Goody (1969) considered it a sort of legal fiction that enabled the attraction of foreigners into the kin universe -thus displacing the gravity centre from consanguinity to contiguity as the base for political action.

By the end of the 1960s and during the 1970s, adoption flourished in ethnographic

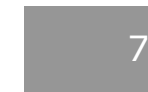




\section{perifèria}

Number 18, june 2013

http://revistes.uab.cat/periferia

projects carried out in Oceania. Edited volumes by Carrol (1970) or Brady (1976) specifically tackled with the strategic nature of adoption in oceanic societies. Hence, concerning the potentially strategic dimension of adoption, Brady stated that:

Adoption is a prime example of conscious, volitional engineering in social life it is a means for resolving conflict, on the one hand, and it is a process that may create conflict, on the other [...] Adoption offers a solution to a broad range of social, economic, and political problems that are likely to develop in small populations attached to island environments, including the insurance of equitable distributions of people relative to the requirements domestic and descent groups may have for heirs, balanced divisions of labor, sibling solidarity, enhanced political power, property alignments, and continuance of the groups themselves as corporate and cooperative entities. (1976:288-289).

Actually, this social engineering does not merely operate upon the formal constitution of adoption. It frequently constitutes more diffuse ways of placement. However, the length of these placements is variable and resulting adhesions may enclose diverse finalities (e.g. to palliate infertility / infecundity, to secure the provision of care at late age, to turn the offspring of a new spouse's into the other's own progeny, to establish a legitimate heir, to find a new home for orphans, to alleviate conjuntural familial precariety, or to strengthen kin and familial ties, among others). We could even find 'adoption' as a social tactic to attract future spouses for your children, as it happens with the T'ung-yang-hsi in China, where some estimations points at a high amount of marriages (up to $40 \%$ ) based on this attraction of future daughter-in-laws into their future household at early age (Wolf 1968:864).

We can find traces of all these goals among monogamous or polygamous societies with different kinds of descent rules, different sorts of subsistence systems and various religious backgrounds. Informal placements can sometimes be found also in connection with marriage patterns and the preferential number of spouses. Thus, Céline Vandermeersch (2002) has shown how in Senegal, the frequency of 


\section{perifèria}

Number 18, june 2013

http://revistes.uab.cat/periferia

placements is in direct relation with the marriage history of women/mothers:

Ainsi, les mères célibataires, celles qui ne vivent pas avec leur conjoint ou celles qui ont connu au moins une rupture d'union placent plus souvent leurs enfants que les mères actuellement en union monogame [...] Conformément aux hypothèses avancées par les anthropologues et les sociologues, cette pratique permet une redistribution des enfants lorsqu'une mère doit faire face à une situation difficile, un divorce, un veuvage, ou une naissance hors mariage et ce, en accord avec les règles de filiation en vigueur [...] De même, les mères vivant en union polygame sont significativement plus souvent concernées par cette pratique que celles vivant en union monogame [...] Le confiage des enfants apparaît donc comme l'expression de la prégnance des solidarités familiales chez les femmes engagées dans des unions traditionnelles (Vandermeersch 2002:663).

Often, this placement is aimed at a different goal: the provision of labourers and servants. For example, in the Carolines, Damas (1983) finds also adoptive practices, all together with the habit of attracting others' offspring much more informally and without changes in the child's affiliation. Such transfers supplies the care provider with cheap labour, be it children, teenagers o even young adults. When adoption is considered, relationality and the acknowledgement of generosity (directly connected to the positive establishment of reciprocal relationships at many levels) are reasons of sufficient importance to be executed:

The material on adoption from Pingelap argues that adoptees move not from large to small families but rather from small families or families not yet formed to small families of families just being formed. It is not difficult to infer the reasons for this apparent anomaly from observation and informant's statements. Couples who have demonstrated fertility are likely to be regarded as selfish if they deny a request from a couple who has been childless for some time. (Damas 1983:334).

The profit of such transfers proves time and again to be multilateral, binding adults 


\section{perifèria}

Number 18, june 2013

http://revistes.uab.cat/periferia

together in contexts where neither placement is not necessarily irreversible nor the affiliation exclusive, since bonds with the origin family should not break after placement. In late XIXth century Mexico, Blum (2007) refers to the circulation of children as an extended practice among less favoured social classes, while middle and upper social layers would opt preferentially for adoption as a process to set up a family. Sometimes, mothers did return to the orphanages to claim for their children retrieval after the hard times were left behind.

The informal circulation of children has had also relational effects among lower classes, as in Brazil, where even the poorest households were willing to welcome an extra child or teenager (Fonseca 2002:2000). Sometimes, these placements were temporary, while others remained permanent.

\section{Servanthood and domestic groups: the extension of child circulation in Europe}

Actually, the connection between mobility at early age and production, servanthood or client-patron relationships was common in the European history. Hence, in his book about the evolution of marriage and family in Europe, Goody stresses the social value of young boys and girls and the uttermost importance of securing their care:

There are several widespread institutions that involve shifting children between domestic groups. The first is wet-nursing, which is essentially a service institution, and may consist in bringing in a servant rather than sending out an infant ('baby-farming'). The second is fostering, which is often reciprocal between kin though it too may have a service component, for it is a practice that it is related to the in-house nursing (nannying) of older children, to servanthood, and to apprenticeship [...] The third is adoption, a practice associated with the problem of heirship (1984 [1983]:68).

The Christian church overtly fought the former two, but could not erase them from social practice. Adoption was a somehow different situation. Its legal exercise was 


\section{perifèria}

Number 18, june 2013

http://revistes.uab.cat/periferia

banned for centuries, thus leading to a serious inheritance disruption in traditional channels, as new conditions for the consideration of legitimacy had to be settled. In that sense, Fauve-Chamoux (1996) recalls the relevance of child circulation as Phillipe Àries presented it in the context of the Western Europe's past:

[...] it would be a distortion to interpret the attitude of traditional societies as one in which the child did not exist, did not count. On the contrary, he was physically necessary for the reproduction of a society that scorned adoption (Ariès 1980:650; quoted in p:1).

Nevertheless, not all forms of child mobility perished with the abolition of the formal adoption, though they were dressed in substantially different clothes. Hajnal pointed out that before marriage young people often circulate between households as servants:

Servants are found in substantial numbers concentrated at young adult ages throughout preindustrial Northwest Europe. It seems highly probable that the circulation of servants made possible the late age at marriage, for service provided a function for young unmarried adults (1982:453).

Furthermore, in Denmark, according to the censuses between 1787 and 1801:

Children, it should be noted, are defined in this kind of tabulation by relationship to the head, not by being under a certain age. No doubt the category included not only biological children of the head, but others in an analogous position in the household, such as children of the wife by a former husband, or even children of a remarried wife's former husband by his first wife (Id.: 456-457).

Seemingly, by becoming servants, children who were not primarily related to the household head were also recounted as part of the domestic group (Kertzer 1991). In this sense, Hajnal words become especially relevant:

Servants are a characteristic and, on average, a substantial components of 


\section{perifèria}

Number 18, june 2013

http://revistes.uab.cat/periferia

rural preindustrial Northwest European households; but unlike the word "child," the term "servant" and its equivalents in other European languages are apt to be misunderstood. The term refers to an institution that, so far as is known, was uniquely European and has disappeared [...] Servants lived as integrated members of the household; in particular they often participated in meals [...] [and] were regarded as members of their master's household (or "family" in the language of the time) (1982:470; emphasis added).

The extension of this phenomenon in the preindustrial north-western Europe was remarkable ("usually over 10 percent, of the total population" -Hajnal 1982:473), what allows Laslett to state that service acted as a sort of second socialization after family, complementing church and school (1987:56).

Burguière added that this circulation: "faisait naître d'autres circuits d'échanges, de prestations réciproques, de conjoints [...] ou se coulait dans les circuits existants [...] Elle favorisait le lien social, diffus, toujours à renouer et à étendre aux dépens des liens du sang, donnés une fois pour toutes" (1986: 642).

Despite the relevance of circulation of children in our (not so distant) past, Breen (1983) stresses that servanthood has remained notably unnoticed for social scientists. In the framework of his research in Ireland, Breen points out that servanthood usually affected young males and females whose parents were often workers or small farmers, which is in perfect accordance with Laslett consideration of servants mostly as "children who had changed households" (Breen 1983:92).

Also in France, from 1789 onwards, helpless minors or those coming from poor households could use their labour force in exchange of food, clothes and even training, what Fauve-Chamoux has labelled "Fosterage 'à la française"" (1996:9). Furthermore, it was not uncommon for close kin to take care of (and responsibility over) children until their emancipation, without resulting in a formal adoption (Grau Rebollo 2011b).

Still concerning the mobility of minors, Parkes (2003) has also pointed out how the 


\section{perifèria}

Number 18, june 2013

http://revistes.uab.cat/periferia

alliance fosterage and other forms of adoptive kinship in Europe (and also in Western Asia) could be also examined under the light of political loyalties and tributary practices to conform tight political alliances. Again, the multilateral profit of the circulation of children greatly contributes to the articulation of society as a whole.

\section{Conclusion}

Diverse kinds of adoption constitute variants of circulation of children, understood as a potentially reversible child's placement (either temporary or permanent) among adult individuals who can already be bound together by family links and who may share responsibilities over the child's care and the authority over his/her behaviour.

I sustain that these forms of circulation (especially those labelled as 'informal') are commonly found in many cultures, including our own in a not so distant past. The extension of those movements within a given society can be quite noticeable. Hence, Laurence Pourchez, after his fieldwork in the Reunion Island declared that:

La circulation des enfants m'est apparue comme un phénomène de grande ampleur: quasiment chaque unité domestique visitée pouvait citer l'exemple d'un don d'enfant au sein de la parenté. Des ces placements, certains apparaissaient transitoires, du type fosterage, alors que d'autres étaient définitifs, parfois officialisés (2004:30).

Most importantly: the circulation of children is not only a matter of individual benefit. Singularly, informal placements contribute also to a broader social profit (Brady 1976), which goes far beyond the particular individuals involved. This circulation -that entails central facets of child adscription and rearing- has been often regarded under different labels (as servanthood, for instance) that, nevertheless, can and must be considered, as Hajnal (1982) or Kertzer (1991) have suggested, within the kinship and family conceptual framework. By so doing, we have to pay due attention to the folk character of procreative ideologies in every 


\section{perifèria}

Number 18, june 2013

http://revistes.uab.cat/periferia

society -including our own- as well as the potentially different formulas for collective sanction of adscription and group membership settled at every particular society.

It is only then that we become aware that the Western spread notion of 'adoption' has precise ideological anchors. The circulation of children, understood from a cross-cultural viewpoint could better explain the centrality and significance of children in broader social scenarios. Also, it could underpin the imbrications of rearing with other social groups' reproduction processes. Finally, it can clearly expose that the articulation of the organization of a human group may be activated not only through the mobility of adult individuals (as Meillassoux -1975suggested), but it could be operated also by means of the mobility of children and the relational tissue subsequently entwined between the individuals -or groupsinvolved. This mobility is symbolically and materially accompanied of economic, strategic and symbolic fluxes between the different agents.

Certainly, a better understanding of these social forms of organization can help us, from an epistemological point of view, to refine our theoretical and analytical tools. It also enables us to reconsider certain ethnocentric assumptions and beliefs by better adjusting them to their original contexts and to cross-cultural spaces of interaction. And last, but not least, it refrains us from ethnocentric projections, which demise the heuristic value of a given research and may conceal the theoretical value of analytical categories.

\section{Bibliografía}

Ariès, P. (1980). "Two Successive Motivations for the Declining Birth Rate in the West". Population and Development Review, 6, pp. 645-650.

Beatty, A. (2002). Changing places: relatives and relativism in Java. London: The Institute. (Accessed via eHRAF World Cultures, Human Relations Area Files, Inc.). 


\section{perifèria}

Number 18, june 2013

http://revistes.uab.cat/periferia

Blum, A. S. (2007). "Abandonment, Adoption and Reproductive Disruption: Transitions in Child Circulation in Mexico City, 1880-1910". Childhood, 14 (3), pp. 321-338.

Borges, D.E. (1994). The family in Bahia, Brazil, 1870-1945. Stanford, Calif.: Stanford University Press. (Accessed via eHRAF World Cultures, Human Relations Area Files, Inc.).

Brady, I. (ed.) (1976). Transactions in kinship: adoption and fosterage in Oceania. ASAO Monograph, no 4, Honolulu: University of Hawai Press.

Breen, R. (1983). "Farm Servanthood in Ireland, 1900-40". The Economic History Review. New Series, 36 (1), pp. 87-102.

Burguière, A. (1986). "Pour une typologie des formes d'organisation domestique de I'Europe moderne (XVIe- XIXe siècles)". Annales. Économies, Sociétés, Civilisations. $41(3)$, pp. $639-655$.

Burridge, K.O.L. (1958). "Adoption in Tangu". Oceania, 29, pp. 185-199.

Carroll, V. (ed.) (1970). Adoption in Eastern Oceania. ASAO Monograph no 1, Honolulu: University of Hawaii Press.

Damas, D. (1983). "Demography and Kinship as Variables of Adoption in the Carolines". American Ethnologist, 10 (2), pp. 328-344.

Evans-Pritchard, E.E. (1940). The Nuer: A description of the modes of livelihood and political institutions of a Nilotic people. Oxford: Clarendon Press.

Fauve-Chamoux, A. (1996). "Beyond Adoption. Orphans and Family Strategies in Pre-Industrial France". The History of the Family, 1 (1), pp. 1-13.

Firth, R. (1963 [1936]). We, the Tikopia: A Sociological Study of Kinship in Primitive Polynesia. Stanford: Stanford Unviersity Press. 


\section{perifèria}

Number 18, june 2013

http://revistes.uab.cat/periferia

Fonseca, C. (2002). "Inequality Near and Far: Adoption as Seen from the Brazilian Favelas". Law \& Society Review, 36 (2), pp. 307-431

(2000). "La circulation des enfants pauvres au Brésil: une pratique locale dans un monde globalise". Anthropologie et Sociétés, 4 (3), pp. 53-73.

Hajnal, J. (1982). "Two Kinds of Preindustrial Household Formation System". Population and Development Review, 8 (3), pp. 449-494.

Goody, J. (1984 [1983]). The development of the Family and Marriage in Europe. London, New York: Cambridge University Press.

(1969). "Adoption in Cross-Cultural perspective". Comparative Studies in Society and History, 11, pp. 55-78.

Grau Rebollo, J. (2011a). "Parentesco, adscripción y crianza: elaboraciones culturales de la adopción internacional y la circulación de niños". Revista de Antropología Social, 20, pp. 31-54.

(2011b). "Estrategias socioculturales de procreación y crianza: de la adopción internacional a la circulación de menores" en Grau, J., D. Rodríguez \& H. Valenzuela (eds.). ParentescoS. Modelos Culturales de Reproducción. Barcelona: PPU, p. 445469.

(2010). "La circulación de menores desde una perspectiva transcultural", en Fons, V., A. Piella \& M. Valdés (eds). Procreación, crianza y género. Aproximaciones Antropológicas a la Parentalidad. Barcelona: PPU, pp. 213-234.

Howell, S. (2006). The Kinning of Foreigners. Transnational Adoption in a Global Perspective. New York, Oxford: Berghahn Books.

Isiugo-Abanihe, U. C. (1985). "Child fosterage in West-Africa". Population and Development Review, 11 (1), pp. 53-73.

Kertzer, D. (1991). "Gender Ideology and Infant Abandonment in Nineteenth- 


\section{perifèria}

Number 18, june 2013

http://revistes.uab.cat/periferia

Century Italy". Journal of Interdisciplinary History, 22 (1), pp. 1-25.

Laslett, P. (1987). "The institution of 'Service' ". Local Population Studies, 40, pp. 55-60.

Leinaweaver, J. B. (2008). The Circulation of Children: Kinship, Adoption and Morality in Andean Peru. Durham and New York: Duke University Press.

_ (2007). "On moving children: The social implications of Andean child circulation". American Ethnologist, 34(1), pp. 163-180.

Lowie, R. (1930). "Adoption Primitive" en E. Seligman (ed), Encyclopaedia of the Social Sciences, New York: McMillan, pp. 459-460.

Marre, D.; Briggs, L. (2009). International Adoption: Global Inequalities and the Circulation of Children. New York: New York University Press.

Meillassoux, C. (1975). Femmes, greniers et capitaux. Paris: Maspero.

Lallemand, S. (1993). La circulation des enfants en societe traditionelle. Prêt, don, échange. Paris: L'Harmattan.

Lévi-Strauss, C. (1949). Les structures élémentaires de la parenté. Paris: Presses Universitaires de France.

Mauss, M. (1924). "Essai sur le don. Forme et raison de l'echange dans les sociétés archaïques". L'Anné Sociologique, 4ème edition. 482 p.

Øien, C. (2006). "Transnational networks of care: Angolan children in fosterage in Portugal". Ethnic and Racial Studies, 29 (6), pp. $1104-1117$.

Panter-Brick, C. (2000). "Nobody's Children? A reconsideration of Child Abandonment" en C. Panter-Brick \& M. Smith (eds.), Abandoned Children, Cambridge: Cambridge University Press, pp. 1-26.

Parkes, P. (2003). "Fostering Fealty: A comparative Analysis of Tributary 


\section{perifèria}

Number 18, june 2013

http://revistes.uab.cat/periferia

Allegiances of Adoptive Kinship". Society for Comparative Study of Society and History, 45, pp. 741-782.

Pourchez, L. (2004). "Adoption et fosterage à la Réunion: Du souci de préservé les équilibres sociaux" en I. Léblic (coord.) De l'adoption. Des pratiques de filiation différentes, Clermont-Ferrand: Presses Universitaires Blaise Pascal, pp. 29-47.

Roby, J. L. and Matsumura, S. (2002). "If I Give You My Child, Aren't We Family?". Adoption Quarterly, 5 (4), pp. 7 - 31.

Tschopik, H. Jr. (1951). "The Aymara of Chucuito, Peru: 1. Magic". Anthropological papers of the $A M N H, 44$ (2), pp. 133-308. (Accessed via eHRAF World Cultures, Human Relations Area Files, Inc.).

Vandermeersch, C. (2002). "Les enfants confiés âgés de moins de 6 ans au Sénégal en 1992-1993". Population (French Edition) 4/5, pp. 661-688.

Wolf, A. A. (1968). "Adopt a Daughter-in-Law, Marry a Sister: A Chinese Solution to the Problem of the Incest Taboo". American Anthropologist, New Series 70 (5), pp. 864-874.

\section{Archivos en línea:}

eHRAF World Cultures, Human Relations Area Files, Inc. (HRAF) at Yale University. Online URL: http://ehrafworldcultures.yale.edu. Last accessed 10/04/2012. 